Dragan G L I G O R A (Hrvatska radiotelevizija, Hrvatski radio) dragan.gligora@hrt.hr

\title{
NASMIJANO BEZUMLJE U IZVANBRODSKOM DNEVNIKU SLOBODANA NOVAKA
}

Primljeno: 8. 1. 2019.

UDK: 821.163.42.09-31 Novak, S.

U radu se nastoji pokazati kako je polazište Novakova romana Izvanbrodski dnevnik "izokrenuti" svijet koji počiva na paradoksu, što utječe na glavne elemente i strategije pripovijedanja. Polazeći od te izokrenutosti, koja je uvelike određena politički i ideološki, nastoji se pokazati da u tekstu prevladava "poremećena perspektiva". Temeljna je strategija u romanu igra jezikom/riječima, njihovim simbolima $i$ značenjima, koja povezuje radnju, kompoziciju, pripovijedanje i označiteljski sloj. Ideologiji i jeziku kao njezinu glavnom uporištu lik Magistra, kojeg naopaki svijet pretvara u ludu i izopćenika, može se suprotstaviti samo "ideologijom šutnje" (za koju znamo iz prijašnjih Novakovih novela: Dalje treba misliti, Južne misli, Treba umrijeti logično) ili taj naopaki svijet može pokušati "potkopati samim jezikom". Kada jezik ne može protumačiti svijet, onda se gube gotovo sve njegove funkcije osim poetske. Međutim, u ovom diskursu ironizira se čak i ta jezična funkcija. U paradigmatskoj sintagmi školjke koja šumi nastoji se utjeloviti individualnost i opravdati literarnost, ali pokazuje se da i taj "zalog" umjetnosti može biti u sebi podrivački i proturječan. Povratkom subjekta na otok zaokružuje se romaneskna cjelina, kao i njegov put. Igra riječima, paradoksima, obratima i zamjenama, kao i "težnja za logičnim umiranjem" "izmiruju se" na kraju trećeg dijela romana, naslovljenog "Nekropola", u "izjednačavanju suprotstavljenih svjetova" i rješavanju problema temporalnosti.

Ključne riječi: alegorija, ironija, paradoks, ideologija, vodvilj, poremećena perspektiva, vrijeme

\section{UVOD}

Izvanbrodski dnevnik svojom je strukturom i zaokruženošću sinteza Novakova pripovjedačkog opusa. ${ }^{1}$ Taj roman nastavlja se na piščeva prijašnja djela ( $I z-$

${ }^{1}$ Kao što navodi I. Mandić u predgovoru objavljenom u PSHK (1977): "Slobodan Novak ostvario je u Izvanbrodskom dnevniku (1977) toliko dosljedno proveden, upečatljiv 
gubljeni zavičaj, Mirisi, zlato i tamjan, Dalje treba misliti, Treba umrijeti logično i fužne misli) ponajprije svojim opsesivnim temama "izgubljenog zavičaja", odnosa između ideologije i subjekta, jezika i šutnje te želje za "logičnim umiranjem". U prijašnjim je djelima već opisan gubitak zavičajnosti, mitskog otoka i djetinjstva, kao polazišta Novakova pripovjedačkog svijeta, i kasnije razočaranje u Revoluciju (u kojoj je i sam sudjelovao). V. Biti tako zaključuje kako je u Novakovim novelama, kao i u gotovo čitavom opusu, presudan pokušaj Pripovjedača da se oslobodi alternative Otoka i Revolucije, ${ }^{2}$ što se u romanu Izvanbrodski dnevnik pokušava konačno razriješiti. Odnos između Otoka i Revolucije, kao jedno od temeljnih uporišta Novakove proze, jest odnos između prošlosti, djetinjstva i mita te budućnosti kojoj je težila Revolucija, ali koja je donijela razočaranje i gubitak iluzija.

Kompoziciju romana objedinjuje cikličko kretanje između otoka i kopna, zaokruživanje literarnog i "životnog" puta. Tri dijela romana, kao tri kompozicijske cjeline: "Jednosmjerno more", "Školjka šumi" i "Nekropola", povezuje Magistar, glavni lik, ujedno i pripovjedač, te kronotop putovanja. U prvom dijelu romana Magistar putuje trajektom s otoka na kopno, ali trajekt ne može isploviti iz luke zbog magle. Nakon što ipak isplovi, nasuče se na svjetionik, a poslije odsukavanja vraća se u luku. Trajekt alegorijski može predstavljati državu s kapetanom-barbom kao njezinim vođom, s podređenom mu posadom kao državnim aparatom i konačno s putnicima kao građanima - podanicima, a stanje te države alegorijski je prikazano kao slika broda u magli, već poznatog toposa izgubljenosti i dezorijentacije. Brod ne može isploviti zbog magle; isplovljava onda kada je magla najgušća i nasukava se na svjetionik, simboličnu zvijezdu vodilju, udarajući u svoju "svijetlu budućnost".

U drugom dijelu romana, "Školjka šumi", Magistar putuje vlakom u Zagreb. U umobolnicu Vrapče sprovodi ga općinski funkcionar Sirena. U vlaku se odvija zamjena uloga, što dovodi do niza obrata i situacija svojstvenih žanru vodvilja. U trećem dijelu romana, "Nekropola", Magistar se vraća iz

i čvrst ironijski pleter, da ga možemo smatrati vrhuncem njegove spisateljsko-graditeljske moći. Zgušnjavajući do krajnosti svoj pogled na svijet - u kratka tri putovanja, naizgled u tri posebne i samostalne pripovjedačke cjeline, ali uistinu u tri poglavlja što čine ovaj kripto roman od nepunih devedesetak stranica - Novak je ovdje dao njegovu radikalnu poentu. Pletući svoj pleter od niti koje se vuku iz pređe dugogodišnjeg sazrijevanja, a reflektirajući u ovoj prozi brojne provodne motive čitavog svog opusa, on je simbolički zaokružio svoju literaturu" (Mandić 1981: 7).

2 "Takvo nezaustavljivo zauzlavanje Novakovih novela rezultat je tvrdokorno opetovanog Pripovjedačeva nastojanja da se oslobodi alternative otoka i Revolucije” (Biti 1994: 92). 
zagrebačke umobolnice na otok kako bi prisustvovao ukopu zbog kojeg su mu općinske vlasti "otele" njegovo posljednje utočište - grobno mjesto. Time se onemogućuje njegova težnja za "logičnim umiranjem”. Putovanje je tako alegorijski prikazan subjektov životni i literarni put i ima narativnu i simboličku dimenziju: otok je ishodište, prijelaz s otoka na kopno jest prijelaz između dvaju zasebnih kronotopa; svijet je nalik na umobolnicu, u kojoj Magistar nalazi privremeno utočište, a povratak na otok prostorno je, vremensko i literarno zaokruživanje cjeline. Cikličnost putovanja odnosno života ${ }^{3} \mathrm{u}$ prvom je dijelu romana povezana ponajprije s tadašnjim aktualnim političkim uređenjem prikazanim u obliku alegorije. Tri dijela romana mogu se žanrovski označiti kao: alegorija, vodvilj i groteska.

\section{IDEOLOŠKA MAGLA}

Ideologija, koja zastire pogled na stvarnost, u romanu je prikazana u obliku magle. Magla je "vlastita vidna smetnja" koja "zastire svijet" i koja se u cijelom romanu pojavljuje u brojnim oblicima - zamagliivanje, objektivna magla, magleno stanje, odmaglio, zvono magle, nabito magleno tijesto, žvačucí maglu, magleni zastor... Magla ovdje nije samo metafora socijalističke ideologije, već ideologije uopće, koja ograničava pogled na svijet i dijeli ga na vidljivo i nevidljivo. Iza ideološke magle ne vidi se "prava zbilja", odnosno svijet onakav kakav jest (ako je to uopće moguće). Magistar je svjestan te ideologije koju promiče jedno društvo, ali i svoje nemoći da se suprotstavi tom sustavu i bilo što promijeni. On zato postaje izopćenik, "medicinski slučaj s radarskim očima" "koji, za razliku od kapetana i ostalih likova, vidi kroz maglu ili iza magle: "Vožnja bi nas možda umivala povjetarcem, ali mi stojimo, sve stoji, magla se više ne ljulja i ne smuca uokolo, nego nam se ona čini kao vlastita vidna smetnja, kao oftalmična migrena koja nam zastire svijet i od koje vidimo mrlju kamo god pogledali" (463). Iako možemo pretpostaviti da se ovdje misli na određenu ideologiju, zapravo je riječ o ideologiji uopće kao sustavu ideja i uvjerenja koji iskrivljuju pogled na stvarnost. Međutim, Magistrova je pozicija naglašena njegovim "uvidom" - on jedini vidi iza

${ }^{3}$ Usp. I. Kovačić: "Ciklička kompozicija ovoga putovanja kroz roman, također se inspirira krugom otoka sugerirajući zatvorenost Magistrove sudbine” (Kovačić Kučić 1991: 161).

${ }^{4}$ Slobodan Novak, Izvanbrodski dnevnik, u: Slobodan Novak, PSHK, str. 464. U nastavku rada navodim brojeve stranica romana Izvanbrodski dnevnik u zagradama. 
magle jer ima "radarske oči” kojima gleda iza ideološki omeđenog i zadanog pogleda i mišljenja, čime se izdvaja njegova pozicija lika izopćenika. Osudu ideologije i težnju za promjenom zamjenjuju deziluzija i rezignacija. Nakon sloma iluzije slijede radikalna deziluzija, ironija i cinizam. ${ }^{5}$ Stoga subjektov put nije put sazrijevanja i spoznaje, već sinkronijski presjek stanja društva u kojem je on već prije spoznao apsurd tog stanja, ali i svog egzistencijalnog položaja koji određuju nemoć i izopćenost: "Što vrijedi meni skupi sjaj moje rezignacije, kad opet dijelim isti mutni vidik s ovim prokletnicima i kad me valja ista mrtvež koja i njih, na istoj splavi s njima, pod istim znacima zlokobnim na nebu" (467), "Svjestan sam ja svoje velike nemoći!" (509a). Stanje rezignacije i nemoći glavnoga lika da bilo što promijeni utjecat će na njegov položaj u tekstu, što će znatno odrediti i retoriku i pripovjedne postupke koji se rabe u romanu. Nemoć subjekta povezana je i s nemoći jezika da obuhvati i izrazi stvarnost, što ću obrazložiti u nastavku rada.

U romanu se najčešće polazi od pojedinačne pripovjedne situacije nakon koje gotovo redovito slijede kraće ironične usporedbe ili nešto duže refleksije koje se često uobličavaju u esejističko-raspravljačke unutarnje komentare koji potvrđuju određeno saznanje o društvu i subjektovu položaju. Pogled 80 pripovjedača s "radarskim očima" povezan je tako i s narativnim postupcima jer on predočava svoj dijegetski svijet tako što ga kazivanjem zapravo sam istovremeno otkriva i stvara, kao što je to metalepsom naznačeno u sljedećem ulomku:

Odšetao sam u maglu vozeći kao puž svoj vidni balon, noseći zvono magle u kojemu me okružuje uvijek isto svijetlo vidjelo kud god pođem: što iz toga kruga izađe - ne postoji više; nema drugih putnika, ni vozača u njihovim zamagljenim kutijama, nema mora, niti obale, izvan moga malog vidokruga gubi se sve u nestvarnome rasteru iza kojeg je ništavilo sasvim blizu, nadohvat, tamo kuda sam maločas prošao, kao da sam tvorac koji pred sobom stvara, a za sobom briše svijet, koračajući samo tlima što ih je za sebe upravo stvorio. (460)

Međutim, pripovjedač-lik u otkrivanju i istovremeno stvaranju svog svijeta u okviru svog "vidnog balona" stalno nailazi na prekide ili nelogičnosti u obliku paradoksa, što je navelo T. Ladana na zaključak da Novakov tekst počiva na paradoksu i da se jedino njime može i objasniti: "Piščev paradoks ne proizlazi naprosto iz nazočne zbilje. Paradoks prethodi dotičnoj zbilji. Zapravo sveukupna se prisutna zbilja kreće prema paradoksu (ukoliko na

${ }^{5}$ Ili kao što je K. Nemec napisao o romanu Mirisi, zlato i tamjan: "Kraj iluzije početak je ironije i radikalne skepse" (Nemec 2003: 126). 
njemu i ne počiva!), i ona se kao takva jedino paradoksom i može odrediti i objasniti" (Ladan 1991: 157). Zato se i radnja razvija putem paradoksa: na brodu "sve je predviđeno tako nepredviđeno" (459a), iz pristaništa se polazi "oduvijek u neprikladno vrijeme" (459b), čeka se onda kada se može isploviti, a isplovljava onda kada je to gotovo nemoguće; trajekt se nasukava baš na svjetioniku, a umjesto domaćeg tegljača ("stare ribarske podrtine") trajekt spašava njemački gliser.

\section{POREMEĆENA PERSPEKTIVA}

$\mathrm{Na}$ temelju do sada navedenog da bi se uopće moglo govoriti o svijetu koji je izokrenut, jedina moguća pripovjedačeva perspektiva jest poremećena perspektiva ${ }^{6}$ (Śkvorc 2005: 248). Naime, perspektiva pojedinca koji u prvom dijelu romana ističe svoj položaj onoga koji "vidi” i želi ukazati na pravo stanje stvari i mogućnost plovidbe pokazala se nemogućom, što je vidljivo i iz sljedećeg komentara:

I koliko god mi se prije činilo jednostavno krenuti u maglu, pogotovu na krilima vjere u nepoznatu navigaciju, toliko mi je sada bilo zlosutno ovo sablasno kretanje kroz još zgusnutije, nabito magleno tijesto, sada, pošto sam vidio onoga Barbu, s njegovim hripljivim i rabijatnim autoritetom, razapetog između sigurnosti i rizika, između odgovornosti i prezira prema toj rulji laskavaca. Bio sam ogorčen što se toliko izdramatizirala bila moja dobrohotna vjera u jednostavnost plovidbe, a sada se ta plovidba hoće prikazati kao rutinska stvar, dok sam ja u malenome izgnanstvu prezren. I sada ću ostati ovdje među ovim bačvama nafte i među smrdljivim cimama kao slijepi putnik, sve dok možda slučajno ne bubnemo o koju stijenu, ili ne strugnemo dnom o pržinu, ili dok pred nas ne iskrsne iz nevidjelice kakav željezni brat pa nas ne zajaše uz tutanj i baraban. Onda će me oni začas izvući nasred palube i optužiti. Ali neće tada reći da sam medicinski slučaj s radarskim očima, a, ne. (464)

Poremećena perspektiva temelji se na paradoksu i obratima: normalno biva nenormalnim, a nenormalno normalnim, moguće postaje nemoguće,

${ }^{6}$ B. Škvorc u radu Obnova ili urušavanje modela: Novak i Ferić (Gorak okus prešućenog) naglašava: "Sam kazivač ovoga teksta pripovijeda u prvom licu i očigledno je da se u sva tri njegova dijela radi o istoj 'poremećenoj perspektivi'. Ta se poremećenost, odnosno izopćenost, u prvom tekstu tek naslućuje i intencijski djeluje prilično 'normalno' razvijajući se narativno kroz alegorijski skicirani put 'u maglu' i povratak, u NIŠTA” (Škvorc 2005: 248). 
a nemoguće moguće, ozbiljno postaje neozbiljno, a neozbiljno ozbiljno. Poremećena perspektiva, koja prevladava u cijelom romanu, dolazi do vrhunca u njegovu drugom dijelu, "Školjka šumi", kada općinski funkcionar iz prvog dijela romana, "mali stručni zločinac" (479a) sada imenovan Sirena, (s)provodi Magistra u zagrebačku umobolnicu. Spoznaja o vlastitoj nemoći (od koje nema neke velike pomoći) prelazi u gnjev ${ }^{7}$ pa onda u rezignaciju koja se u ovom dijelu romana konačno pretvara u "obijesnu" jezičnu igru. Istovremeno se radikalizira i subjektova izopćenost, koja će uskoro postati potpuna i konačna: tom svijetu on više ne pripada "niti svojim pepelom" (479b). Zato ostavlja iza sebe ("u tom tamo svijetu iza mene" (479c)) taj konvencionalni, uređeni i naoko razumni svijet i gleda ga iz perspektive "paranoidnog shizofreničara" ili "nezavisnog paranoika". Izopćenost i poremećenost u tako podvojenom svijetu dodatno se naglašavaju udvostručivanjem slike u ogledalu - subjektova "slika" na samom početku drugog dijela romana izokrenuta je jer "izlazi" iz ogledala željezničkog zahoda - Magistra iz zrcalnog odraza gledaju "dvije staklene loptice nasmijana bezumlja":

Od mene je ionako preostala samo još ova treperava slika u krastavu ogledalu željezničkog zahoda, slika što podrhtava i poskakuje od landranja spavaćih kola na noćnim kolosijecima, iz koje gledaju sjajne oči pomračene duše, dvije staklene loptice nasmijana bezumlja. (479d)

Taj prvi prizor svjedoči o višestrukom podvajanju: pripovjednog i doživljajnog Ja, individualnog i kolektivnog, vanjskog i unutarnjeg te razuma i ludila. Sada se to podvajanje i obrtanje šire na sve strukturne komponente romana i dodatno pojačavaju zamjenom uloga povezanom $s$ izgubljenim ispravama ${ }^{8}$ jer je Magistar Sirenine isprave, navodno, bacio u zahodsku školjku. Skrivanjem ili bacanjem (uništavanjem) isprava mogu se privremeno zamijeniti i uloge aktera, što se rabi kao glavna narativna strategija u drugom dijelu romana:

7 "Ne, nije strah, nego sve ovo ovdje i sve ono dosad. Neizmjerljivo i nenaplativo. To povraćanje svuda oko mene. Ta mučnina u želucu, gađenje u grkljanu. Ta prokleto jasna i ponovno potvrđena spoznaja da sam u lošim rukama, pod krivim zapovjedništvom, da ćemo svi skupa ovoga puta promašiti čak i taj banalni cilj u čiju sam suvislost čini se bio ipak nekako maglovito povjerovao u onoj magli. Da se povlačim cio dan po tuđim izbljuvotinama i da će me istresti zbljuzgana i omamljena na obalu s kojom sam se željno oprostio napuštajući je u drugim nadama. Da sam toliko toga protisnuo već kroz lubanju, te nisam više siguran niti u svoje mentalno zdravlje, premda mi je danas svjetlost ovoga nebeskog svjetionika rasvijetlila na tren pomućenu pamet, kako bih konačno shvatio da sam nepovratno prepušten šarlatanima” (475).

8 "Moja životna diploma! Paranoidna shizofrenija. Jer svaka je diploma... i dijagnoza, ujedno. Jer svaka je dijagnoza ujedno i diploma. I tako već kojim redom hoćete...” (481). 
I tako, pokušao sam mu mirno objasniti kako se sada odjednom ne zna tko je od nas dvojice umobolnik: Magistar ... nome nescimus... kojemu nismo, evo, ni imena upamtili... ili općinski funkcionar Sirena... (482a) Ja mogu biti oj ludi li vi, a vi možete biti oj lud li ja. Komora ili Vrapče. Funkcionar ili pacijent. Dnevnice ili menaža. (487a)

Simbolika zamjene uloga temelj je vodviljske igre, čime se potvrđuje još jedan u nizu obrata, odnosno paradoksa. Zamjena uloga ne otkriva samo izokrenutost svijeta, već rađa još jedan apsurd: subjekta ne određuje njegova osobnost, već isprave, koje jedine "potvrđuju" njegov identitet. Time se razobličuje ono što bi trebalo biti jednim od temelja uređenog vanjskog svijeta - individualnost. Kod Magistra identitet je skriven u školjci, odnosno morskom pužu, a kod Sirene u zahodskoj školjci - "Ali ako nekima kažeš: školjka šumi, oni će najprije pomisliti na engleski zahod! Jer im je duša u sifonu, srce u kloaki, i jer im je mašta obudovjela pa rađa samo posmrčad, i svaki je taj istresak mrtvorođenče!” (487b). Za razliku od vanjske uniformiranosti (posebno tadašnjeg društvenog kolektiviteta) školjka koja šumi, odnosno lubanja (Magistrova glava), govori o identitetu i subjektivnosti, o vlastitom poimanju svijeta koje se razlikuje od poimanja većine ostalih likova, uglavnom predstavnika vlasti i birokracije: činovnika, policajaca, čuvara, službenika, funkcionara, kapetana, političara, odnosno svih onih koji predstavljaju državni aparat:

Normalni misle na praznu morsku školjku, onu što stoji na kaminu, na komodi, na kapetanskom stolu. Kad se prinese uhu. Na zvukove što su se zaglavili pa se kovitlaju [...] Normalni obično misle... to što sam rekao. A ja koji nisam normalan, ja ipak ne mislim ni na školjku, ni na puža, nego na ovu svoju glavu. (488)

U praznoj školjci, u tome nesretnom pužu... samo su i jedino zvukovi! Ništa drugo. U mojoj lubanji samo moji šumovi. Vode nema. Nitko drugi ne čuje školjku što je prinosimo uhu, i nitko ne čuje što u tuđoj glavi tutnji. (489)

"Školjka koja šumi" svojevrsna je metafora individualnosti i potpuno je oprečna administrativnoj ispraznosti dokumenata, iskaznica, putovnica, dijagnoza i diploma, kojima se pokušava odrediti i omeđiti nečija osobnost. Subjektova je individualnost jedinstvena, neponovljiva, drukčija od svih ostalih, osobito kada razmišlja na način koji je različit od vladajuće ideologije ili bilo kakve ideologije, uniformnosti i konvencionalnosti, što se često naglašava u svim dijelovima romana.

Dok u prvom dijelu Izvanbrodskog dnevnika prevladavaju opreke: odlazak/povratak, vidljivo/nevidljivo i mirovanje/kretanje, koje ukazuju na (ne) 
mogućnost plovidbe, u drugom dijelu prevladavaju opreke: kolektivno/ individualno, vanjsko/unutarnje i razum/ludilo. Magistar se tako na (privremenom) izlasku iz umobolnice nalazi između vanjske i unutarnje slobode. Vanjsko je ono što je "serijski sortirano", uniformirano, jednolično i naizgled logično i razumljivo. Uredan razumski poredak uniformira i "skladno" svrstava ljude, koji se ponašaju po određenim konvencijama i pravilima, čak su i slično odjeveni, slično se ponašaju i govore: "Zajednički se pjeva, ždere, viče, konferira! Sve u serijama i konfekcijski. Sve u povorkama! Ja sam i ovdje kao i onamo opet sam, jedini čovjek s pogrebnim vijencem kao s državnim grbom preko ruke" (514a). Za razliku od vanjskog, razumski uređenog svijeta pojedinac traži svoju slobodu i identitet u ludnici. ${ }^{9}$ Tom lažnom svijetu institucija i konvencija on će suprotstaviti identitet "slobodnog luđaka", a školjka koja šumi postat će provodnim motivom i simbolom te individualne, ali i umjetničke slobode. Međutim, Magistar pritom mora odigrati posebnu ulogu - on na sebe mora "staviti" masku ludaka ili lude jer jedino na taj način može govoriti ono što drugi ne mogu. Naime, ulogu luđaka koji to nije može igrati jedino luda - lik koji povezuje ludilo i ludens, bezumlje i igru, čime (ovakva) književnost postaje jedna vrsta "razigrane ludosti", odnosno 84 "nasmijanog bezumlja", jer više se ne referira izravno na stvarnost, ne želi (i ne može) promijeniti svijet, ne može se ostvariti kao jedinstven subjekt, i zato pokušava tu ideološku posredovanost nadići samom jezičnom igrom. Luda je lik koji može, na svoj način, reći ono što ne može nitko drugi. U svojoj poznatoj studiji $O$ romanu Bahtin piše o likovima obješenjaka, šaljivčine i lude koji razobličuju laž institucija i njihov konvencionalni govor: obješenjakova obmana parodira visoke jezike, šaljivčina izvodi preokretanje, a luda se koristi naivnim nerazumijevanjem:

Obešenjak, lakrdijaš i luda stvaraju oko sebe posebne male svetove, posebne kronotope. [...] Ti likovi u književnosti sa sobom donose, prvo, vrlo bitnu vezu s pozorišnom scenom na trgu, sa pozorišnom maskom na trgu, oni su povezani sa jednom posebnom, ali veoma bitnom deonicom narodnog trga; [...] To su glumci života, njihovo postojanje podudara se s njihovom ulogom, a izvan te uloge oni uopšte ne postoje. (Bahtin 1989: 281)

Bahtin smatra da su to tri važne dijaloške kategorije koje su organizirale govornu raznolikost u romanu u osvit njegove povijesti (Bahtin: 1989). U

9 “Tamo gore u onoj našoj ludnici ja sam jedini magistar, jedini dobrovoljni zatočenik bez ozbiljne dijagnoze, jedini ekspert za školjke bez rakova, jedini u svemu i svačemu; i ostali pacijenti tamo su jedini, svaki u svojoj vrsti i podvrsti (iznimku čine izvjesna tri Hitchcoka)" (514b). 
liku Magistra spajaju se upravo ta tri aktera jer on: parodira "visoke jezike", posebno politički i literarni diskurs, zatim obrće situaciju i koristi se naivnim nerazumijevanjem. Bahtin navodi kako jedan od osnovnih zadataka romana postaje razobličavanje konvencionalnosti i lažne uvjetovanosti svih ljudskih odnosa. ${ }^{10}$ Kraljevski dvor ili trg na kojem luda izvodi svoj "vodvilj" sada postaje cijeli svijet koji je izokrenut: "Ali ludnica je, naprotiv, meni ovaj uredni maxi-svijet, koji je sav izokrenut" (491). Bahtin govori o ludi i obješenjaku, spadalu i šaljivčini kao likovima koji nisu ono za što se predstavljaju, oni žive samo u svojoj ulozi, a izvan nje ne postoje. Zato je motiv školjke na neki način i svojevrsno opravdanje pripovjedačeva postupka. Iz njega izviru kalamburi, igra riječima, ironija, deestetizacija, parodija i paradoks. Jezik je predstavnik književnosti, svijeta, ali i same individue pa je, prema tome, književnost na taj način sadržana u školjci koja šumi, koja proizvodi vlastito, posebno značenje. Međutim, jezik (pa tako i jezik književnosti), kao što smo vidjeli i kao što ćemo dalje vidjeti, može postati i utočište ideologije, kao i svega površnog, istrošenog i negativnog. Stoga se školjka koja šumi ne može promatrati jednoznačno. U njoj se krije i jezična i životna proturječnost zvuci koji se kovitlaju na izvjestan način predstavljaju određenu paralipsu. Pripovjedač nam nikada neće (ili ne može) otkriti što se u toj školjci zapravo događa. Ona je s jedne strane simbol koji može sadržavati i ključ razumijevanja romana, ali recipijentu je njezin šum nedohvatljiv - kao da ga sam subjekt namjerno krije od ideološki utemeljenog jezika koji će tu njezinu jedinstvenost banalizirati i "oskvrnuti”. Jezik gubi svoje izvorno značenje (komunikacije i spoznaje) i postaje "izvrnuti" jezik konvencija, ideologije, naopakog svijeta i konačno laži, o čemu, na sličan način, govori i francuski teoretičar Georges Gusdorf u članku "Ja sam ja” ("Ich bin ein ich”):

Svi naši čini su u biti krajnje osobni, jedinstveni, individualni, neusporedivi; sigurno, no čim ih svijest prevede u jezik, prestaju izgledati takvima [...] Svijet kojega možemo postati svjesni samo je površni svijet znakova, poopćen, vulgariziran svijet; i kao posljedica toga sve što postaje svjesnim istodobno postaje

${ }^{10}$ Vidi Bahtin: "Tu borbu sa konvencionalnošću na dubljoj i načelnoj osnovi nastavlja roman. Pri tome se prva linija, linija autorske transformacije, koristi likovima spadala i lude..." (Bahtin 1989: 281). "Svi ideološki oblici-instituti postajali su licemerni i lažni, a stvarni život, lišen ideološkog smisla, postajao je životinjski sirov" (Bahtin 1989: 281). Škvorc pak govori na sličan način o postideološkom stanju kod Ferića, kod kojeg više nema ideologije kao kod Novaka, već ona postaje animalnom: "Tako je postideologija zapravo ipak fingirana: mi je živimo kao vlastito ideološko polazište suprotstavljeno religijskom, nacionalnom ili metafizičkom. Ideologija je sve bliže animalnom, pohlepi i pohoti, a sve dalje od božanstvenog. Ali je još uvijek to, ma koliko se nazivala postideologijom" (Škvorc 2005: 259). 
površnim, mršavim, glupavim, postaje općom stvari, znakom, brojem u stadu; svako poistovjećivanje povlači za sobom bitnu koncepciju svojega predmeta, veliko krivotvorstvo, opovršnjenje, uopćavanje. (Gusdorf 2000: 196)

\section{JEZIČNI OBRAT}

Općinski službenik Sirena, koji prati Magistra do umobolnice, nema identiteta, ${ }^{11}$ on je samo simbolički predstavnik Komore, to jest Partije, činovnik koji se ponaša po određenim pravilima i zato ne može shvatiti Magistrovu igru. Sirena ne može shvatiti ni Magistrovu ironiju: "Nemojte se, veli, igrati ozbiljnim stvarima... Jer to je Sireni ozbiljno! Taj vodvilj” (482b). Takvo ograničeno gledanje na svijet ne može uspostaviti nikakav dijalog s nekim drugačijim tumačenjem svijeta i stvarnosti. Zato je između pisca i ideologije onemogućen dijalog, on se može samo poigrati tim i takvim svijetom, ali ta igra ipak ima "gorak okus prešućenog" (Škvorc).

U Novakovoj noveli Dalje treba misliti, koja je objavljena prije Izvanbrodskog dnevnika, ono bitno, koje je uvelike i politički konotirano, još uvijek postoji, ali se o njemu ne može izravno govoriti. Stoga se govori/piše o nebitnom, a ono glavno prešućuje se ili se ironizira. Taj postupak, koji je Novak nazvao ideologijom šutnje, povezan je na određen način i s ideologijom priče:

To hoću da kažem, kada je riječ o ideologiji šutnje. Ili, svejedno, recimo: ideologiji priče. Hoću da kažem: valjalo bi šutjeti o bitnim stvarima. Ili, svejedno, recimo: pričati o nebitnim. Tako se ne može postati jedan od bezbrojnih sizifa ili tantala. Bogovi tako ne znaju gdje nam je peta, a kažnjavaju nas samo prema našem jeziku koji je nešto posve drugo. (Novak 1981c: 179)

Ideologija šutnje tako, još jednim obratom, postaje ideologijom priče, odnosno pripovijedanja, koja se temelji na pripovijedanju o nebitnom da bi se izbjegao gnjev bogova - vladajućih ideologa. Međutim, u Izvanbrodskom dnevniku ni tog (skrivenog) bitnog više nema, "nego je sve svejedno", što upućuje na nemoć, skepticizam, relativizam i nihilizam te na gubljenje subjektove jake pozicije i na urušavanje modela kasnog modernizma, nagovješćujući ideje i postupke svojstvene poststrukturalizmu i postmoderni.

11 "Ali on je tvrdokorno jašio na svojim dokumentima, na čistoj i urednoj zdravstvenoj knjižici, koje i nema, na osobnom identitetu, makar sam mu uljudno objasnio, da ima on vraga crnoga, da nema ništa, nikakav identitet, i da ne može podastrijeti ni takvu mačju ogrebotinu kao ja" (483). 
Ako više nema ničeg važnog o čemu treba govoriti (ili šutjeti), ako više nema "velikih priča" i ideja, ako više ništa "stvarno" ne djeluje, pa tako ni istrošeni konvencionalni jezik, onda se nameće pitanje što i kako dalje govoriti kada toga "glavnoga više nema":

Danas bih mogao kao slobodni luđak rikati okolo sve što sam nekoć prešućivao. Pa i ono glavno. Kada bi toga još bilo. Samo - glavnoga više nema. I to je, morali bismo reći, ipak žalosno, zar ne. Premda, samo po sebi - i nije. $\mathrm{Ne}$, nije nimalo! Nego je upravo svejedno, kao što je sve svejedno; kao što je sve, sve, sve svejedno! (509b)

Magistrov je položaj politički određen pa se pripovjedač obilato koristi zabludama vladajuće ideologije, njezinim političkim govorom, birokratskom ispraznošću, kao i ispraznošću cijelog partijskog aparata. Međutim, pripovjedač implicitno naznačuje kako je nemoguće zauzeti neku (meta)poziciju koja bi bila izvan samog simboličkog poretka, odnosno jezika, kada nam upravo taj simbolički poredak omogućuje da govorimo. No, da bi uopće mogao govoriti, glavni lik, kao što sam već naveo, mora navući masku lude, "nezavisnog paranoika" ili "slobodnog luđaka". Stoga se Magistrova izopćenost i rezignacija mogu shvatiti i kao latentan revolt zbog nemogućnosti da se "uobičajenim" jezikom, jedinim oruđem i oružjem pisca, dosegne ono bitno. Otud u Novakovim djelima prevladava poigravanje riječima i frazama, citatnost, ironija i autoreferencijalnost. Ali, on je isto tako svjestan da se gomilanjem, raz-vodnjavanjem riječi, pretjerivanjem do krajnjih granica može razvodniti “taj moj vodvilj u još tanju posvemašnju bevandu” (492). Stoga se sada postavlja pitanje granica samoga jezika koji prelazi u igru koja postaje samoj sebi svrha. Međutim, Novakovo majstorsko poigravanje jezikom ipak je "gušće" od bevande. Primjerice, poigravanje riječju voda, njezinom etimologijom i izvedenicama, ne svodi se samo na zgodne doskočice ili efektnu igru riječima, već se kroz cijeli roman provodi na složen i slojevit način. Jer voda se isto tako može povezati s riječju vodvilj. Igra asocijacija nastavlja se s riječima koje su povezane s korijenom vod: vodovod, vodoskok, voditi, vodvilj, voditelj (“moj voditelj” - Sirena), zavod, odvoditi (u policijsku postaju), provoditi, zavoditi (kondukterku u tramvaju), sprovoditi (u ludnicu), "putni sprovodnik" (Sirena), sprovod (gospojice Valerije). U prvom dijelu romana Barba je vođa, a brod plovi pod krivim vodstvom i nasukava se na "zvijezdu vodilju". Gliser isto tako spašava, vuče brod, kao što je to trebao napraviti tegljač - "odvesti" trajekt u luku. Često ponavljanje riječi voda i voditi, odnosno imenica i glagola s korijenom vod zasigurno nije slučajno. Te riječi i sintagme (vezane uz vodu i glagol voditi) mogu upućivati na: 
1. riječ voda, koja ima doslovno i simbolično značenje

2. vodenje i odvođenje Magistra u ludnicu i policijsku postaju

3. krivo vodenje, u političkom smislu, koje je ironizirano

4. (za)vodenje samog autora jezikom, odnosno simbolikom i igrom riječima

5. ideološko vođenje $i$ zavodenje (koje je povezano i s maglom, jednim od stanja vode, kondenzacijom vodene pare u zraku)

6. sve to konačno vodi sprovodu, odnosno smrti.

Voda je, dakle, na neki način povezana s vođenjem prema nečem izuzetno važnom (i ontološkom i narativnom), što određuje cijeli treći dio romana, "Nekropolu". Čini se kao da riječi na jednoj razini "preuzimaju" dominaciju i same vode neku svoju unutarnju igru, ${ }^{12}$ što naglašava i sam pripovjedač koji govori o "elegantnim besmislicama", "specifičnom verbalističkom sadizmu" $\mathrm{i}$ informacijama iz "prve lingvističke ruke". Tako se neke riječi i sintagme (magla, voda, školjka, brod i grob) uporno i opsesivno ponavljaju i nameću u tekstu, ukazujući na neka druga značenja, ali i na druga Novakova djela, koja su prethodila Dnevniku. Zato je i vodvilj ironiziran kao što je ironizirana i pripovjedačeva pozicija. Pripovjedač pokušava naći svoju ulogu u tekstu i uspostaviti odnos sa subjektom, njegovim svijetom i jezikom, odnosno dijegetskim svijetom, diskursom koji nastanjuje. Dolazi do međusobnog izigravanja i poigravanja jedne diskursne instance s drugom, zato u tekstu nailazimo na brojne zamjene uloga: onoga tko vidi i onoga tko ne vidi, voditelja i vođenog, luđaka i normalne osobe, pa čak i pacijenta (luđaka) i liječnika, a na kraju se događa i bizarna zamjena grobova.

Vrhunac tog poigravanja upravo je u drugom dijelu romana, kada Magistar, zajedno sa Sirenom, posjećuje svog osebujnog prijatelja Predraga Rorauera koji "konverzirajući besmisleno" govori "elegantne besmislice".

${ }^{12}$ Usp. M. Dedaić koja u svom članku "Ironično/ironijska igra jezičnim elementom u prozama Slobodana Novaka" pronalazi igre homonimima i polisemima, neologizmima, sastavljanjem i rastavljanjem riječi, skraćenicama, sličnim likovima riječi, frazeologizmima, ustaljenim i "izlizanim" izričajima i situativnim izrekama: "Neke su riječi slične po fonološkoj slici, neke imaju slična značenja, neke su homofoni, neke homografi, neke homonimi; te slučajnosti otkriva pisac, igrajući se njihovim izrazima i sadržajima, a tada one postaju otkriće i za čitaoca" (Dedaić 1991: 198). U tekstu se često rabe i ironične metafore i perifraze: telefon - prgava bakelitna beštijica; tegljač - niska ribarska škrebetaljka, ribarska podrtina; trajekt - bivša desantna jedinica, rashodovana jedinica, željezni brat, šuplja trupina; radnici - prvi jutarnji kopači; pogrebni vijenac - cvjetni kotač sa šuštavim vrpcama, objekt uznemirenja; svjetionik - ćorava lanterna, kula namiguša, dioptrička stella maris; magla - nabito magleno tijesto, objektivna magla, zamagljene kutije, zvono magle. 
Ta jezična igra, posebno u ovoj narativnoj sekvenci, već poprima obrise "besmislenog verbalističkog sadizma":

Uveo nas je s mnogo lijepih i bezvrijednih riječi, pa tako i s uzrečicom: "U mene vam je uistinu radna atmosfera", na što se, začudo, Sirena lecnuo, i stao ispričavati, kako ne bi htio da smetamo, ali je i doktor Neno brzo prozreo svoju elegantnu besmislicu, i smijući se i klikćući objašnjavao: "Kome?! Meni?! Ni govora! To je samo atmosfera! Atmosfera! Onako. Više nered! Šta ja tu mogu?! Protiv te atmosfere ne možemo ništa!" (497)

Usto dobiva još jednu funkciju. Naime, kada putem asocijacija "zablista" igra označitelja, koja u pojedinim dijelovima ima i humorna obilježja, kao da diskurs, pa i samog njegova naslovljenika, "oslobađa" od ideologije i njezina jezika, od nametnute vlasti jednog oblika jezika i mišljenja. Kada jezik ne može protumačiti svijet jer je, između ostalog, već potrošen i nedostatan za to, onda se gube sve njegove funkcije osim one poetske, umjetničke funkcije, koja postaje samoj sebi svrha. No, u ovom diskursu dekonstruirana je čak i ta funkcija jer je jezik (pa i poetski) zapravo jedno od najčvršćih uporišta ideologije. Zato se toj tiraniji jezika, koja se događa na svim razinama, može suprotstaviti samo "ideologijom šutnje", ali kako nju u književnom djelu nije moguće ostvariti, onda jezik treba pokušati razoriti razotkrivanjem njegovih konvencija. To razaranje nastavlja se u cijelom romanu. Jer Novak u Izvanbrodskom dnevniku doslovno ne štedi ništa: Crkvu, obred ukopa, smrt, život, međuljudske odnose, slobodu, znanost, ljubav i ljepotu (sa svom njihovom istrošenom i lažnom frazeologijom), pa čak ni samu instituciju književnosti. Novak se često, ne samo u ovom djelu, poigrava citatima iz hrvatske (uključujući i narodnu) ili svjetske književne baštine tako da ih parafrazira, parodira ili citira na ironičan način:

Ali nema takve duhovne vježbe koja bi me smirila pred prijetnjom i pogibelji ovoga sada naglog izlaska, putovanja i povratka na Otok. Ne može to ni ovo blistavo jutro što me dočekuje u bolničkome vrtu, najljepše ljetno jutro što ga je ikad svjetska književnost zabilježila, da tako glupo kažem! Ne. Uistinu, kada bi se bilo čija suhoparna opažanja bacila sada na papir, mogla bi ona već samo po tom i takvom jutru ući u književnu povijest, ako bi se vjerno upustila u pojedinosti. (507)

Sve je to još čudnije kada znamo da je Novakov subjekt u prijašnjim tekstovima težio šutnji kao potvrdi vlastitoga bitka. U noveli Dalje treba misliti o spomenutoj ideologiji šutnje kaže kako nam ona može "pomoći da budemo kakvi jesmo, bez opasnosti da postanemo junaci" (Novak 1981c: 179). Svijet izmiče tumačenju već i zbog same ideologije, ali ne samo zbog 
nje, već i zbog jezika koji nas kao simbolički oblik udaljuje od neposredne stvarnosti i koji je zasićen konvencijama pa je, prema tome, i sam na neki način ideologiziran ili je pak instrument ideologije. Na sličnom je tragu Frederic Jameson koji simbolički poredak smatra istovremeno izvorom svih značenja, ali i svih klišeja: "prava slavina svih nižih, značenjskih efekata kojima je zasićena naša kultura, pravo sjedište i locus neautentičnoga u Heideggerovu smislu" (1978: 119), dok anarhoprimitivist John Zerzan čak tvrdi da se jezik može smatrati fundamentalnom ideologijom (Zerzan 2004: 45).

\section{OD (B)RODA DO (G)ROBA}

Nakon što se "obračunao" s lažnim poimanjem individualnosti, ispraznom ideologijom i istrošenim jezikom kao njezinim neizbježnim subjektom, pa čak i sa samim tekstom koji nastanjuje, Magistar se kao izopćenik i luda s pogrebnim vijencem u ruci vraća brodom na otok. Međutim, ta aporija jezika, odnosno simboličkog poretka, naravno, nije razriješena jer sada se otvara još niz ključ90 nih pitanja koja zahtijevaju (raz)rješenje. Treći dio romana, "Nekropola", na posredan način pokušava razriješiti upravo ovo pitanje: treba li "Nekropola" zaokružiti romanesknu cjelinu u kojoj je jezik možda i glavna tema, koja je neraskidivo povezana s nemogućnosti izricanja istine i samom smrti, ili cijeli roman treba shvatiti kao samosvrhovitu i duhovitu jezičnu igru "nasmijanog bezumlja" koja ostaje unutar teksta jer izvan teksta ništa i ne postoji? Ili treba ostaviti barem "prividnu vezu" teksta sa stvarnošću i povezati problematiku jezika i šutnje s nagonom za smrću. V. Biti “odgovara”:

Po Freudovoj analizi, šutnja je egzemplarna manifestacija nagona za smrću. Žudnja za njom je, međutim, podjednako paradoksalna kao i žudnja za grobom. Obje potječu iz važnosti za jedan izgubljeni poredak. Život je težeći za samopotvrdom zanijekao u sebi smrt, jezik je to učinio sa šutnjom. Zbog toga subjekt, pritiješnjen osjećajem krivnje, pokreće annullamento retroattivo - po Olivininoj analizi manirizma - "pokušaj da se delovi koji leže nepomično u dubini pomere ka izražajnom korišćenju.” (Biti 1991: 109)

I doista, najvažniji dio završnog dijela romana događa se upravo na groblju. Magistar se vraća na otok kako bi prisustvovao pogrebu, ali ne zna tko je umro, što obznanjuje s izrazitim sarkazmom: "Javili su odozdo da je netko u obitelji preminuo. Drugoga bi to možda radovalo, ako se uzme jedno s drugim. Mene ne, mene gnjavi” (506). Povratak iz ludnice na otok označava se kao prijelaz "iz šuplje slobode u praznu” (509c), što je još je- 
dan paradoks koji potvrđuje izokrenutost svijeta i razobličuje metafizičke kategorije: "Krenuti, međutim, odavde u slobodu, kako li je uopće moguće, kada sam nekoć iz te slobode tamo - ozbiljno mislio da ću je naći ovdje!" (508). Naopakost svijeta u čijem temelju leži apsurd potvrđuje se i na otoku otkrićem ilirske nekropole ispod gradskog groblja. Budući da je nekropola vrijedan arheološki nalaz, nameće se i kao moguća lokacija koja će obogatiti turističku ponudu. No, to otkriće stanovnicima otoka uzrokuje problem jer nemaju gdje pokopati mrtvaca, u ovom slučaju Valeriju, i to u jeku turističke sezone. Evo kako to gradski oci objašnjavaju Magistru pokušavajući ga pridobiti da svoje grobno mjesto ustupi za ukop Valerije:

Oni kažu da je ta nekropola još iz vremena ilirizma, a to može lako biti, samo što je sve to ispod zemlje, na žalost, i baš specijalno ispod našeg gradskog groblja, eto tu smo, vidite. Zato ja kažem: šume, gliseri, komunalije, svaki vrag na nas ovo ljeto, i sad još ovih dana našli konzervatori te ilirce na tako neprikladnom mjestu! Ne kažem, to je i te kakav događaj! Ali... smeta! Mi smo svi svjesni toga što to znači takvo naučno iskapanje arheologije, ali smo mislili, neće biti problema, u nas umire jedan i nijedan čovjek godišnje, a dotle će se osposobiti novo zemljište, jer konzervatori ne dopuštaju da se itko više ovdje zakapa... (522)

Time poigravanje jezikom prerasta u jezivu grotesku jer, uz sve navedeno, subjekt gubi i vlastito grobno mjesto. Budućnost je u nekropoli, što je s jedne strane krajnji paradoks i apsurd, a s druge istina. Ta potpuna izokrenutost pojma vremena višeznačna je jer se umjesto sretne budućnosti pronalazi groblje, kao mjesto na kojem završava čovjekov život, što znači da za njega vrijeme prestaje teći i poništava se u ništavilu. U Novakovu dijegetskom univerzumu za čovjeka ne postoji čak ni pojam vječnosti jer će njegove kosti kad-tad dograbiti i konzervirati znanost. Zato se brod, kojim Magistar na početku romana pokušava otići s otoka, a na kraju se njime na otok vraća, (metaforički) ustremljuje ravno na groblje. Brod i grob na taj način povezuju otok, kao ishodište i rod, i vodu koja otok okružuje i koja se može prijeći samo brodom. Brod, otok, školjka i grob svojevrsni su mitemi koji imaju neka zajednička obilježja, a suprotstavljeni su im voda, magla, odnosno vođenje, sprovođenje i zavođenje kao "negativni oblici". Magistar se vraća na otok noseći u ruci "objekt uznemirenja" - pogrebni vijenac, ${ }^{13}$ što ukazuje na to da je put od umobolnice do otoka zapravo put

${ }^{13} \mathrm{U}$ prvom dijelu romana ključne su riječi brod i magla, odnosno sintagma "brod u magli"; u drugom su to školjka i voda, odnosno "školjka šumi”, a u trećem pogrebni vijenac i grobnica. 
na vlastiti sprovod: "Budućnost koja danas upravo završava, jer ja s ovim vijencem ispraćam možda sebe sama i zauvijek se vraćam na ishodište gdje sam začet i gdje me čeka grob” (519a). Nošenjem pogrebnog vijenca Magistar simbolički označava putovanje prema vlastitoj smrti, ali i ona mu je uskraćena jer su mu općinske vlasti “otele" njegovo grobno mjesto. Budući da mora "zamijeniti" svoje grobno mjesto s Valerijom, sestrom bivše ljubavi Primorkinje Vile koju susreće na brodu, ne može ostvariti svoju nakanu za logičnim umiranjem koja se spominje u noveli Treba umrijeti logično. Odmah iza navedene rečenice o budućnosti koja završava upravo riječju grob slijedi rečenica koja počinje riječju brod:

Brod šiba hrptom po svom ležaju, razgrće sukrvičastu i bolesno zapjenjenu iznutricu starog mora, kao da skida ružičastu bundu ležeći u kaljuži. Ustremio se ravno na groblje. Sunce odjednom prljavo smeđežuto uplovljava u visoku kaladu iznad Plavnika, tek što je prevalilo drugu trećinu neba. Sekret moga srca vodenkast je i mutan kao sugnojica. Raspada se biće, tvar i duh... Budućnost je već za nama. (519b)

Već na samom početku romana, odmah nakon dolaska na trajekt Magistar se želi uvući u utrobu (broda), "gdje je brod najbrodskiji”, odnosno u "najnjedrija njedra broda", kao fetus u maternici, odnosno kao mrtvac u grobu. Kao što na početku romana želi leći u utrobu broda, tako na kraju želi leći u grob. ${ }^{14}$ I ovdje se nameće specifična igra riječima koja upućuje na dublje značenje u tekstu i povezuje dijelove romana svojom semantičko-retoričkom igrom. Ta igra riječi dobiva se naknadno rastavljanjem i premetanjem slogova i riječi, njihove etimologije, zvukovne sličnosti i semantike, i upućuje na cikličku igru životnog putovanja: od roda (otoka) do

${ }^{14}$ Do sličnog zaključka dolazi i V. Biti u studiji "Avanti adagio, quasi indietro": "U Izgubljenom zavičaju vrijeme Otoka, cikličko smjenjivanje godišnjih doba, i vrijeme Revolucije, zasnivanje novog početka 'odiljanjem' u smjeru budućnosti, bili su jasno, i grafički i kompozicijski razdvojeni. [...] Kao jedinstveni mise en abîme toga strukturnog čvora, koji bi se (s više dopuštenog prostora) mogao otkriti podjednako na mikrostrukturnoj razini rečeničnog nadovezivanja i na makrostrukturnoj razini opusa, pojavljuje se Pripovjedačeva katatonična žudnja za utrobom čamca (ispod pramca u Izgubljenom zavičaju), broda (Riba fanina), kripte (Crvena mrlja na člu), mrtvačkih kola (Operacija Opel), grobnice (Treba umrijeti logično), nekropole (Izvanbrodski dnevnik). Taj opsjedajući regressus ad uterum stojeći s jedne strane u znaku rastućeg nagona za ponavljanjem, s druge je radikalizirani Ungeschehenmachen. U utrobi čovjek počiva u obliku čvora. Njegovo čelo dotiče koljena. Budući da se bez čela ne može biti Junakom kao što se ni bez koljena ne može biti Žrtvom, njemu su uskraćene i Revolucija i Otok. Utoliko, on je više nego mrtav. No s gledišta činjenice da ni jedan od tih zavodničkih ambijenata još nije dospio nastaniti, on je više nego živ" (1991: 93). 
kopna i povratka na otok. Brod kojim se Magistar vraća na otok spaja otok i kopno, zvukovno upućuje na grob, metaforički se ustremljuje na groblje. Oblik broda, odnosno njegove unutrašnjosti sličan je obliku utrobe, pa se često i u svakodnevnom govoru rabi sintagma utroba broda. Utroba broda (ili groba iz kojega se javlja rod(bina): otac i tetka) aludira na začeće, odnosno rođenje, početak životnog ciklusa. Tako se u semantici riječi grob sastaju brod, kao oznaka plovidbe i traženja, ali i transgresije, prijelaza ${ }^{15} \mathrm{~s}$ otoka na kopno, ${ }^{16}$ i rod, od kojega se odvaja i ponovno mu se vraća. Brodom se vraća na otok na kojem se nalazi i grob, koji je u tekstu jednom označen i kao korablja, a na određen se način povezuje i sa školjkom u kojoj se i ovdje kovitlaju zvuci: "U njoj je odzvonio moj tihi korak po šljunku, a onda su se kao u školjci kovitlali neprepoznatljivi zvukovi tuleći i trubeći na polazak. Bio je čas da se krene: da se nepozvan ukrcam u ovu korablju k svojima - ili da, isto tako svojevoljno, pođem još malo onamo po svijetu?" (535). Kao i kod riječi voda, koja se isto tako može povezati i s rođenjem i s brodom, ne radi se samo o igri riječima, nego o tome da ta povezanost između riječi rađa i određene narativne strategije, međusobnu povezanost određenih dijelova teksta koja se očitava na više dijegetskih razina. $\mathrm{Na}$ taj se način potvrđuje da je temeljna strategija u romanu igra jezikom/riječima, njihovim simbolima i značenjima, koja povezuje radnju, kompoziciju, pripovijedanje i označiteljski sloj. Roman tako teži zaokruživanju života kao ciklusa, ali i zaokruživanju vremena. Može se govoriti o nesvjesnom povratku u mitsko vrijeme vječne sadašnjosti, ali i o spoznaji da je taj pokušaj unaprijed osuđen na propast.

\section{BUDUĆNOST JE VEĆ ZA NAMA}

Ako je "sve svejedno", ima li uopće smisla tragati za izgubljenim vremenom i bilo kakvim smislom, jer je i ta potraga već opovrgnuta i ironizirana? Pripovjedač u Izvanbrodskom dneviku inzistira na pojmu vremena kao budućnosti i pita se doslovno: je li to ta budućnost?, pa zaključuje, vjeran paradoksu, kako je budućnost već za nama. Polazak s otoka u prvom dijelu romana polazak je isto tako u budućnost. Ironiziranje socijalističke "svijetle budućnosti" pri-

${ }^{15}$ Etimologija riječi brod upućuje na mjesto (plićak) preko kojeg se moglo prelaziti s jednog mjesta na drugo.

${ }^{16}$ Novak je brodom isto tako prešao s otoka na "putove revolucije". Taj događaj odlaska brodom u partizane spominje se u romanu Izgubljeni zavičaj. 
sutno je već u prvom dijelu romana, kada se trajekt nasukava na svjetioniku koji bi trebao pokazivati put u tu sretnu budućnost kao "zvijezda vodilja". ${ }^{17}$ Prošlost je zauvijek izgubljena, a s njom i otok - "izgubljeni zavičaj”, a sadašnjosti nema jer je ona uvijek ustremljena prema kretanju, prema plovidbi (kao i brod), prema budućnosti. U Novakovim je djelima stalno prisutna čežnja za odlaskom s otoka, za plovidbom u budućnost, u "otkrivanje svijeta", ali i razočaranje tim svijetom. Povratak na otok nije povratak u prošlost, a ne može biti ni povratak u budućnost jer je i budućnost potrošena, ona je "već za nama". U romanu se naglašava dihotomija između ideologizirane budućnosti i "metafizičke" budućnosti koja završava vraćanjem na ishodište, odnosno u smrt, jer je zapravo smrt "svih nas budućnost". ${ }^{18}$ Otok je ishodišno mjesto, mitsko mjesto na kojemu se začinje idila, koja je opisana u Izgubljenom zavičaju. Mit je izgubljen, a umjesto njega nameću se revolucija i znanost. No subjekt više nema iluzija ni o revoluciji, čiji je pristaša nekad bio, ni o otoku, ${ }^{19} \mathrm{~s}$ kojim se davno oprostio, a koji je sada postao utočište "krepanih turista", demitiziran i deestetiziran. Na kraju će znanost, kojoj ništa nije sveto, uništiti ono što nisu uništili politika, vrijeme i ideologija; znanost uništava i samu vječnost, pa čak i one preostale ljudske vrijednosti i svetinje.

94 Mit se pretvorbom revolucije i znanosti, kao i društvenim uređenjem može na određen način transformirati u književnost, ali i ona je demitizirana, pa od mita možda nije ostala ni priča, jer je i ona na određen način demistificirana i ironizirana, kao što su dekonstruirani i njezini postupci, njezina gradba i kompozicija te stil i retorika. Odlazak s otoka na kopno može biti samo odlazak u prostor otuđenja, kao u romanu Mirisi, zlato i tamjan. S otoka se može otići jedino u ludnicu i ondje pokušati naći prosperitet, koji je groteskno utjelovljen u Posripetu, lokalnom pogrebniku-amateru, svojevrsnom otočnom Haronu. ${ }^{20}$ On simbolički pokapa budućnost.

${ }^{17}$ Barba je vođa, svjetionik zvijezda vodilja, a Sirena voditelj i sprovodnik, dok je Posripet Prosperitet, dakle budućnost koja vodi na groblje, pogrebnik i sprovodnik, on preuzima od Magistra upravljanje ceremonijom na groblju.

18 "I sada, tako da kažemo, u toj vražjoj nekropoli naša je budućnost, druže Magistre! Svih nas budućnost!" (521).

${ }^{19}$ Negdje pri kraju romana Izgubljeni zavičaj Novak ističe: "Sada kada brod ulazi u luku, treba priznati barem da je Otok nekada bio moj zavičaj, i da to znaju i ljudi koji su ovdje zavičajni. Ali zavičaja zapravo nemam i ne znam da li mi je danas i potreban” (Novak 1981b: 72).

${ }^{20}$ Usp. Škvorc: "Umjesto kraja ideologije i njezina (ponovna) pretvaranja u mitsko, odnosno priču, dolazimo do situacije afirmacije negativne ideologije, odnosno grotesknog i podrivačkog koje se istovremeno odnosi prema dvama entitetima: izvanjezičnoj stvarnosti koju imitira i 'visokoj književnosti' koju ironizira i podriva njezino usustavljivanje" (Škvorc 2005: 266). 
Kako Novak razrješava to pitanje vremena? U opisu obreda ukopa, na posvećenom prostoru, gdje se spajaju rođenje i smrt i gdje bi se konačno mogla zaokružiti ta putanja, nastavlja se jezična igra u kojoj prevladava groteska: zvono se na ulasku povorke u groblje "mahnito naklepetalo", a grobnice se uspoređuju s Disneylandom: "Uspravne grobnice u dvoredu čine središnju uličicu groblja, kao palačice u slikovitome Disneylandu" (531). Kutija u koju se stavljaju kosti zapravo je kartonska ambalaža s oznakom alpsko mlijeko. I svetost groblja uništili su simboli moderne civilizacije: Disneyland, kartonska ambalaža i arheološka iskapanja. Otok, ludnica i grobnica mogu biti tri mjesta, tri toposa izopćenja kamo se može pobjeći od stvarnosti, ali su i ta tri "sveta" toposa demitizirana, tako da Magistar na kraju odustaje od "logičnog umiranja" i pronalazi rješenje u tome da treba nadživjeti one koji su ga ubili: "Treba putovati, treba jesti ciklu, južno voće, gledati dijalektički. Nadživjeti one koji su me ubili!” (536a). Međutim, na samom kraju romana, u "dodiru" sa smrću, mijenjaju se i pripovjedni ton i retorika - jezična igra, ironija i kalamburi prelaze u mračnu filozofsku meditaciju u kojoj se iščitava kraj putovanja i razrješenje problema vremena:

Bio je čas da se krene: da se nepozvan ukrcam u ovu korablju k svojima - ili da, isto tako svojevoljno, pođem još malo onamo po svijetu? Čekao sam do sumraka hoće li "pogrebno poduzeće" doći sazidati ovdje demarkacioni parapet što dijeli moju budućnost nadvoje. Ali slog lišajastih opeka ukraj staze, neočišćenih, ogrezlih u staru žbuku, ostao je neuzidan. Tama iz grobnice pline polako oko mene, kao da suklja iz podzemlja, uvlači se u čemprese i razvija među grmlje, obavija križeve i razlijeva se stazama... suprotni svjetovi se izjednačuju, nestaje ona granica što dijeli svjetlo od tame, vječnost od prolaznosti. U grobnicu sad mogu zakoračiti kao u kutak svog života - iz groblja mogu otići kao da idem u smrt. Smrt i život ostali su sada još samo u meni, ali u meni nerazdvojni, pomiješani u mojim klijetkama, u mojim tobolcima i mjehurima. U sebi nosim svoj put i svrhu, i sada je doista svejedno kamo krećem i da li krećem. Sve svejedno. (536b)

Odustajanjem od smrti pripovjedač zapravo prekida kružni ciklus, isključuje se iz kruga točno na toj njegovoj krajnjoj točki, tangenti koja bi trebala spojiti rod (otok), brod i povratak na otok, odnosno u grob. U tom trenutku prestaje igra obrata i zamjena, suprotni svjetovi sada se spajaju, a smrt i život, vječnost i prolaznost izjednačuju se, i to u samom subjektu. To znači da se subjekt poistovjećuje s vremenom, ali je nemoguće do kraja dokučiti i shvatiti i pojam subjekta i vremena koje ga nastanjuje.

Međutim, zaključni iskaz na samom kraju romana, da "možda nešto i bude od svega ovoga" ne treba shvatiti doslovno jer od svega toga i ne može 
biti ništa upravo zato što je sve svejedno, pa više nema ničeg bitnog, dakle više nema nikakve vrijednosti kojoj bi se moglo težiti, nikakve svrhovitosti tog životnog puta, i zato se on naglo prekida u trenutku kada se sve izjednačuje. To naposljetku kazuje i zadnji paradoks u romanu, da treba nadživjeti one koji su ga ubili. Ta tvrdnja može imati i političku konotaciju i ukazivati na partijsku strukturu koja je uništila državu i samog subjekta, ali i na smrt jednog poimanja književnosti i umjetnosti.

\section{ZAKLJUČAK}

Odustajanje od groba, od logične smrti, kojoj vode cijela struktura, ideja i narativna potraga romana istovremeno je i njegov vrhunac i pad. U "tehničkom" (kompozicijskom, ideološkom i narativnom) smislu Novak je iznašao rješenje da zaokruži roman, ali jedino se rješenje može naći u rezignaciji, u tome da je sve svejedno, što je u skladu načelima postmodernizma gdje zapravo više nema metafizičkih vrijednosti, pa čak ni uobičajenog poimanja smisla i gdje se ne zna točno je li pripovjedač-subjekt doista lik koji spaja sve ključne sastavnice romana: "Smrt i život ostali su sada još samo u meni, ali u meni nerazdvojni, pomiješani u mojim klijetkama, u mojim tobolcima i mjehurima. U sebi nosim svoj put i svrhu, i sada je doista svejedno kamo krećem i da li krećem. Sve svejedno" (536c). Da, sve te narativne, idejne i diskursne sastavnice spajaju se u jednom liku - ali tako da život i smrt u njemu postaju neraskidiva instanca. Smrt je već nastanjena u životu, ona ga podriva od samog početka, kao što podriva njegov smisao i svrhu. Umjesto praznog govora zahtijeva se ideologija šutnje, koja upravo u ovom romanu doživljava svoj paradoks jer ne samo da se šuti nego se govori naveliko o nebitnom i to je "besmisleno konverziranje" postupak svojstven postmoderni kada se sve urušava i kada se postavlja samo pitanje ideologije i jezika. $\mathrm{Na}$ kraju tako dolazimo i do onog nerješivog pitanja odnosa između literature i zbilje, koje je posebno tematizirano u modernoj i postmodernoj književnosti i umjetnosti. Odnos između jezika i ideologije nije razriješen, kao ni odnos između ideologije šutnje i ideologije priče. Voda, vođenje, zavođenje, odvođenje, privođenje, sprovod, dovod upravljaju tekstom, kao i ideologijom, a ostaje školjka koja šumi svojim jezikom, koji može postati vrhunska jezična igra, ali i potvrda vlastite egzistencijalne i literarne individualnosti. No, kao što smo već rekli, ona je u sebi proturječna i nedokučiva i ne može se nikada do kraja ostvariti, osim u umjetnosti koja postaje jedina utjeha urušenom subjektu koji nastanjuje već unaprijed izokrenuti ideologizirani svijet. 
Nagon prema smrti koji je prikazan u brojnim Novakovim tekstovima također je povezan s jezikom i njegovim simboličkim poretkom, $\mathrm{s}$ književnim postupcima koji ravnaju tekstom, ma koliko to ironiziranje prerasta u vodvilj, u igru zamjena unutarnjeg i vanjskog, šuplje i prazne slobode, zadanog i oslobođenog jezika, vječnosti i prolaznosti. Osobito je odbojan odnos prema kolektivnom, zajedničkom, općem poimanju stvari, prema uređenosti svijeta koji je sav izokrenut, pa se onda izokreće i sam jezik, koji pritom postaje zalogom užitka u njegovoj igri, u vrhunskoj izvedbi samog diskursa. U jednom trenutku mogli bismo se složiti s Barthesovim poimanjem užitka u tekstu: "Užitak u tekstu je upravo to: vrijednost promaknuta na raskošni označiteljski položaj” (2004: 153). ${ }^{21}$ Međutim, krajnji zaključak opet se nameće u samoj umjetnosti, jer je usprkos svemu Izvanbrodski dnevnik vrhunsko jezično djelo koje može imati čak i ulogu svojevrsnog pročišćenja, katarze koja svojom izvedbom opet upućuje na život i književnost kao dvije instancije koje mogu međusobno komunicirati iako im sve stoji na putu da to ne ostvare. Skup sjaj spoznaje i rezignacije ne donosi subjektu nikakvo rješenje, kao ni revolt, koji u romanu ipak postoji, ali je i on prezren, odbačen i ironiziran. Iako se subjektova pozicija u ulozi pripovjedača nastoji zadržati iznad svih drugih instancija, u njoj se spajaju sva diskurzivna polja teksta i stvarnosti čija je paradigma školjka koja šumi, koja ujedno dopušta i opovrgava cijeli taj napor oko uspostave teksta koji se neumitno raspada, kao što se u jednom trenutku prije dolaska na otok "raspada biće, tvar i duh".

Ti pokušaji ipak iznjedruju određen užitak u tekstu jer roman je zaokružena cjelina koja u jednom trenutku, kao što sam rekao, može načas osloboditi od tiranije svijeta i jezika, znanosti, običaja, aparata i komore, vođa i "svijetle budućnosti". Pokušaj da se prevlada samo vrijeme tako da ono ostane "za nama" možda ostavlja trag bezumnosti, odnosno "nasmijanog bezumlja”, što je, moglo bi se reći, bit ovoga romana i subjekta koji se ipak oslobađa želje za logičnim umiranjem jer je smrt već u njemu. Bez obzira na neka kasnije objavljena djela, kao što je Pristajanje, Izvanbrodski dnevnik zaokružuje proznu cjelinu od mita do demitizacije, od pastorale do groteske i time ostavlja subjekt bez zavičaja i revolucije, dovodeći ispripovijedani svijet do izokrenutosti i groteske.

${ }^{21}$ Ovdje smo na tragu neke druge, ali slične teme, odnosno nekog novog rada koji bismo, primjerice, mogli nasloviti "Raskošni (jezični) užitak Izvanbrodskog dnevnika". U tom bismo se radu više mogli pozabaviti odnosom između užitka i ideologije u tekstu ili odnosom užitka i znanja, ne samo u procesu proizvodnje teksta i analizi semantike diskursa nego i u recepciji romana. 
D. Gligora, Nasmijano bezumlje u Izvanbrodskom dnevniku Slobodana Novaka (77-99)

"Umjetnost riječi" LXIII (2019) • 1-2 • Zagreb • siječanj - lipanj

\section{LITERATURA}

Bahtin, Mihail. 1989. O romanu. Beograd: Nolit.

Barthes, Roland. 2004. Užitak u tekstu. Zagreb: Meandar.

Biti, Vladimir. 1991. "Avanti adagio, quasi indietro, Čvor subjekta u prozi Slobodana

Novaka". U: Republika 47, 3-4: 102-112.

Biti, Vladimir. 1994. Upletanje nerečenog. Zagreb: Matica hrvatska.

Cassirer, Ernst. 1985. Filozofija simbolickib oblika. Novi Sad: Dnevnik.

Cvitan, Dalibor. 1971. Ironični narcis. Zagreb: Matica hrvatska.

Dedaić, Mirjana. 1991. "Ironično/ironijska igra jezičnim elementom u prozama Slobodana Novaka". U: Republika 17, 3-4: 196-208.

Derrida, Jacques. 1976. O gramatologiji. Sarajevo: Svjetlost.

Flaker, Aleksandar. 2003. "Otočne rošade (Šoljan i Ferić)". U: Postmodernizam, iskustva jezika u brvatskoj književnosti i umjetnosti. Ur. Cvjetko Milanja. Zagreb: Altagama: $9-16$.

Gusdorf, Georges. 2000. "Ja sam ja”. U: Autor, pripovjedač, lik. Ur. Cvjetko Milanja: Svjetla grada - Pedagoški fakultet Sveučilišta Josipa Jurja Strossmayera: 151-197.

Havelock, Erich A. 2003. Muza uči pisati. Zagreb: AGM.

Jameson, Frederic. 1978. U tamnici jezika. Zagreb: Stvarnost.

Kovačić Kučić, I. 1991. "Otočnost u karakteru Novakovih likova”. U. Republika. 47, 3-4: 159-164.

Ladan, Tomislav. 1991. "Od sinegdohe do paradoksa i natrag”. U: Republika 47, 3-4: $156-159$.

Levi-Strauss, Claude. 2001. Divlja misao. Zagreb: Golden marketing.

Mandić, Igor. 1981. Slobodan Novak. Predgovor u PSHK. Zagreb: Nakladni zavod Matice hrvatske.

Milanja, Cvjetko. 2000. Autor, pripovjedač, lik. Osijek: Svjetla grada.

Muhoberac, Mira. 1991. "Smisao sudbine, sudbina smisla: Novakov Hlap". U: Republika 47, 3-4: 119-136.

Nemec, Krešimir. 2003. Povijest hrvatskog romana od 1945. do 2000. Zagreb: Školska knjiga.

Nemec, Krešimir. 2006. Putovi pored znakova. Zagreb: Naklada Ljevak.

Novak, Slobodan. 1981a. Izvanbrodski dnevnik (PSHK). Zagreb: Nakladni zavod Matice hrvatske.

Novak, Slobodan. 1981b. Mirisi, zlato i tamjan (PSHK). Zagreb: Nakladni zavod Matice hrvatske.

Novak, Slobodan. 1981c. Tvrdi grad (PSHK). Zagreb: Nakladni zavod Matice hrvatske.

Oraić Tolić, Dubravka. 1990. Teorija citatnosti. Zagreb: Grafički zavod Hrvatske.

Škvorc, Boris. 2003. "Obnova ili urušavanje modela: Novak i Ferić”. U: Postmodernizam, iskustva jezika u brvatskoj književnosti i umjetnosti. Ur. Cvjetko Milanja. Zagreb: Altagama: 209-230.

Škvorc, Boris. 2005. Gorak okus prešućenog. Zagreb: Alfa.

Šnajder, Đuro. 1971. Uvod u najnoviju brvatsku prozu. Zagreb: Matica hrvatska.

Van Dijk, Teun A. 2006. Ideologija. Zagreb: Golden marketing.

Zerzan, John, 2004. Anarhoprimitivizam protiv civilizacije. Zagreb: Naklada Jesenski i Turk.

Žmegač, Viktor. 1991. "Parerga uz djela Slobodana Novaka”. U: Republika 47, 3-4: 65-71. 
D. Gligora, Nasmijano bezumlje u Izvanbrodskom dnevniku Slobodana Novaka (77-99)

"Umjetnost riječi" LXIII (2019)・1-2 • Zagreb • siječanj - lipanj

\section{Abstract}

\section{SMILING INSANITY IN OUTBOARD LOG BOOK BY SLOBODAN NOVAK}

The paper argues that the starting point of Novak's novel Outboard Log Book is a "twisted" world based on a paradox, which influences the main elements and strategies of narration. Due to this "twisted" feature of the novel, which is determined mostly politically and ideologically, the "disturbed perspective" prevails in the text. Since the basic strategy in the novel is the pun, i.e. world play, whose symbolism and meanings interconnect the plot, composition, narration, and the signifiers. The character of Magistar, transformed into a fool and an outcast in this upside-down world, can oppose the ideology and language as its main stronghold, only with "silence ideology" (known from previous Novak's novels We Should Think Further, Southern Thoughts, and It Should Die Logically.), or he can try "to undermine it with the language itself". When the world cannot be interpreted by language, almost all its functions are lost. What remains is the poetic function that becomes embedded in irony. The paradigmatic syntagm a shell that makes a noise embodies the individuality and further justifies literariness. However, it becomes obvious that even that "pledge" of art can be both disruptive and contradictory. The protagonist's return to the island signals a circular structure of the key narrative strand, as well as his journey. Puns, playing with paradoxes, twists and replacements, as well as "the aspiration for logical dying" "are reconciled" at the end of the third part of the novel entitled Necropolis, which is visible in the "equalization of the opposing worlds", and in finding a solution to the problem of temporality.

Keywords: allegory, irony, paradox, ideology, vaudeville, disturbed perspective, time 